\title{
worldview
}

A JOURNAL OF RELIGION AND INTERNATIONAL AFFAIRS

\section{CITIZENS AND THE ISSUES}

As problems of foreign policy grow more complex, the possibilities for intelligent citizen participation in shaping them seem to grow more remote. Indeed, Mr. Dwight Macdonald, writing in the latest issue of Commentary, argues that even the attempt at citizen involvement in questions of national policy is a waste of time. Foreign policy, he writes, "is an area where it might theoretically make a difference which party or candidate one voted for ... But it is just here that (a) the amateur voter cannot be expected to have any sensible opinion, and (b) there is no detectable difference between the parties." Our national elections are thus "elaborate techniques for avoiding rather than resolving issues."

Mr. Norman Podhoretz, the editor of Commentary, tends to agree. In his editorial on the Macdonald observations he writes that the President "is bound by intractable conditions that can only be manipulated within very severe limits. Nixon, it is safe to say, would act no differently from Kennedy or Humphrey in a critical situation ... To that extent, national politics in America have come to resemble . . . the game of 'ins' and 'outs' that characterized eighteenth century politics in England. Intellectuals can hardly be expected to take much interest in the game, since they are accustomed to thinking of politics in ideological terms and are happier when they can confront a situation in which the right contends unambiguously against the left." The moral? If intellectuals wish to change the world "let them work on the consciousness of their age and forget about parties and movements."

There is obviously a large measure of truth in what Mr. Macdonald and Mr. Podhoretz say. Our society has reached a level of stability (they might call it inertia) where any major shifts in national policy, any radical departures from the norm, are politically impossible. The old arguments between laissez-faire capitalism and a welfare state are settled: we have a welfare state and the only question between the politicians is whether it shall be conserved as it is or expanded. The old arguments between isolationism and internationalism are settled, too: the question now is what forms our internationalism will take.

But the uses to which Mr. Macdonald and Mr. Podhoretz put these truths are dangerous. Stability and consensus within a society do not mean the end of politics: to think so is to define politics as fratricide. Rather, they mean that politics can be creative in a way that would not be possible were the basic structure and goals of a socicty not agreed upon.

This is particularly true in the area of foreign affairs. The foreign policy issues that both politicians and voters should define and debate this year would not be issues at all had not the fundamental directions of American foreign policy already been decided.

Mr. Macdonald, apparently, would have a politics of the barricades or no politics at all. But the real issues in politics are seldom so dramatic; they may even seem pedestrian or academic and "far removed from the life of the average citizen." But they can still, within the context of the given "intractable conditions," make all the difference to the nation's prosperity and even to its survival.

The average intelligent citizen, the "amateur," is not compctent to decide the technicalities of the defense debate or the complexities of the budget, but he can make an informed judgment on political and economic priorities, on which aspects of our national program he thinks should be put first. In 1952 he could, and should, have had some views on the "containment" or "liberation" argument, and in 1960 he can, and again should, have views on whether our present and future response to the challenge of world Communism should be primarily military or economic.

These, and many others, are questions over which the citizen has some control; they are not remote from his concerns or alien to his interests. They are the real issues that must involve us allpoliticians and citizens-this election year. 